\title{
DESIGN AND PERFORMANCE ANALYSIS OF A FIVE PHASE INDUCTION MOTOR WITH SPWM TECHNIQUE
}

\author{
GAJULA SOWMYASRI $^{\mathbf{1}}$, ANUGULA RAJAMALLAIAH ${ }^{2}$ \& BANDELA SATHYAVANI $^{\mathbf{3}}$ \\ ${ }^{1} P G$ Scholar, Department of Electrical and Electronics Engineering, SR Engineering College, Warangal, TS, India \\ ${ }^{2,3}$ Assistant Professor, Department of Electrical and Electronics Engineering, SR Engineering College, Warangal, TS, India
}

\begin{abstract}
In this manuscript modelling and performance analysis of five phase induction motor (IM) with sinusoidal pulse width modulation (SPWM) technique is presented. Machines are backbone to the any industry to get more production. Three phase IM motors are majorly suffering with speed controlling and ripples in torque response. These drawbacks are cause to overall system performance is sluggish, poor voltage regulation and less efficiency. These problems are overcome much extent by adopting five phase IM. In this paper a basic SPWM employed to operate voltage source converter (VSC) fed IM drive is investigated. This SPWM technique mitigated ripples in torque response of IM and improved speed performance of the IM approximately near to synchronous speed. From the simulation results it is evident that proposed SPWM fed IM drive prohibits desired performance characteristics over the other well known PWM techniques in the literature. The simulation results are investigated in MATLAB/software environmental.

KEYWORDS: Five Phase IM, Sinusoidal PWM, Speed, Torque Ripple, Voltage Source Converter
\end{abstract}

Received: Jun 08, 2020; Accepted: Jun 28, 2020; Published: Aug 19, 2020; Paper Id.: IJMPERDJUN2020818

\section{INTRODUCTION}

To fulfil any new innovation to the world the role of electricity and electrical machineries are plays a crucial role. The performance of machine is notable important to safe and continuous operation of industry [1-2]. The main challenge in front of electrical engineer is to drive the machines smoothly and reliable to obtain the more production. IM are widely accepted AC machines in any industry over the synchronous and DC machines because of its numerous advantages such as easy construction, inferior maintenance required, low cost and over a wide range of speed control is possible [3-4].

The speed control of three phases IM is presented by various authors in the literature. In this various approaches converter topologies fed IM drive are gave improved performance of the system those are cascaded bridge fed IM [5], flying capacitor fed IM [6], neutral diode fed IM [7]. To design these topologies involves a lot of mathematical analysis. These converter topologies have more number of power electronic switching components so transient or failure occurrence is very high. High power switching devices are employed like SCR, IGBT etc to operate safe switching pattern control algorithm is required. Control algorithms are broadly categorised in two ways conventional and expert optimized control strategies. The conventional control strategies [8-10] works well for fixed output response. It has fixed PI tuning parameters. Where in optimization algorithms like fuzzy, neural, genetic algorithm, etc..., error is calculated for each time and varied PI values compensated and desired output is achieved. Design and operate IM drive with converter topologies are bit difficult. Other than these converter topologies direct torque [11-12] and direct power [12-13] control approaches are famous to design IM drive. To 
extract maximum torque with this approaches require knowledge about IM drive.

Unlike three phase IM, five IM are becomes more popular because the speed control of five phase IM is very simple and obtained more output so efficiency of the system is increases to a greater extent. In this paper five phase IM is designed with SPWM and obtained ripple free torque output and enhanced overall performance of the IM drive.

The next sections of this manuscript is organized as follows described configuration of five phase IM in sectionII, elaborated about SPWM technique in section-III, in section-IV mentioned the simulation results and summarized conclusions of this manuscript in section-V.

\section{SYSTEM CONFIGURATION}

The structure of SPWM based VSC fed five phases induction motor is illustrated in fig.1a

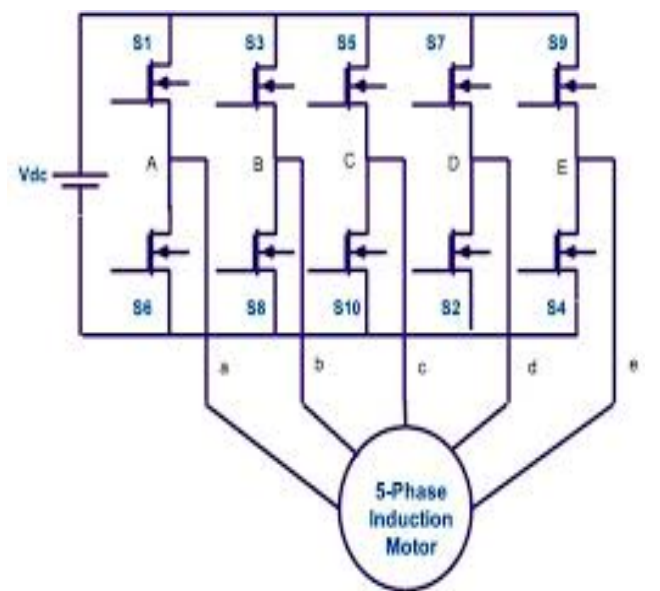

Figure 1a: VSC Fed Five Phases IM.

The stable DC source i.e. battery, fly wheel energy is converted in to AC supply with VSC and supplied to the stator of the IM.

The mathematical model of five phases IM is described below. For better understand five phase IM is expressed as dq0 axis the equivalent circuit of five phases IM in dqo axis is exposed in fig. $1 \mathrm{~b}$ below.
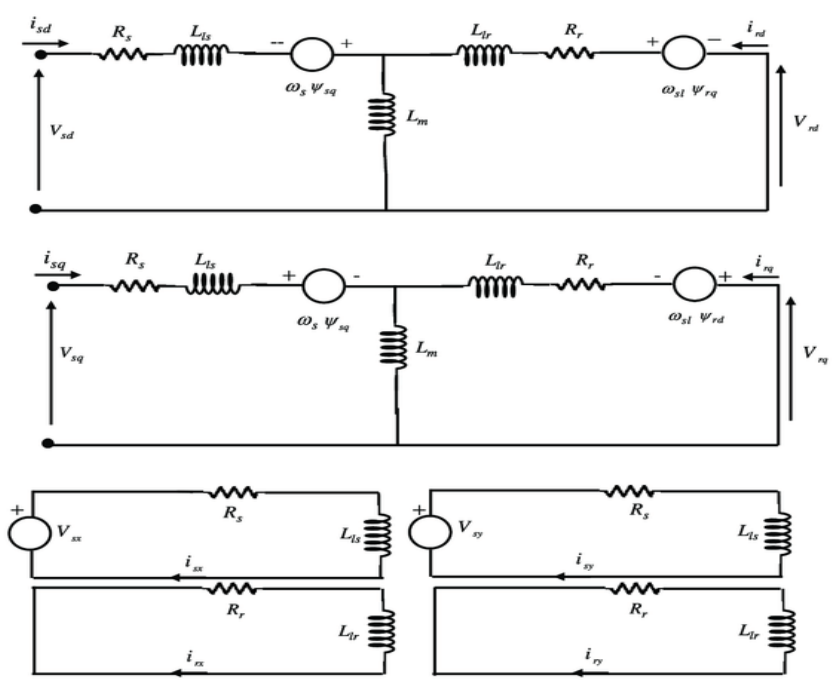

Figure 1b: Equivalent Circuit of Five Phase IM in DQO Axis. 
The remodelled equations of a five-phase induction machine are given as;

$$
\begin{aligned}
& \mathrm{V}_{\mathrm{ds}}=\mathrm{R}_{\mathrm{s}} \mathrm{i}_{\mathrm{ds}}-\omega_{\alpha} \psi_{\mathrm{qs}}+\mathrm{p} \psi_{\mathrm{ds}} \\
& \mathrm{V}_{\mathrm{qs}}=\mathrm{R}_{\mathrm{s}} \mathrm{i}_{\mathrm{qs}}-\omega_{\alpha} \psi_{\mathrm{ds}}+\mathrm{p} \psi_{\mathrm{qs}} \\
& \mathrm{V}_{\mathrm{xs}}=\mathrm{R}_{\mathrm{s}} \mathrm{i}_{\mathrm{xs}}+\mathrm{p} \psi_{\mathrm{xs}} \\
& \mathrm{V}_{\mathrm{ys}}=\mathrm{R}_{\mathrm{s}} \mathrm{i}_{\mathrm{ys}}+\mathrm{p} \psi_{\mathrm{ys}} \\
& \mathrm{V}_{\alpha \mathrm{s}}=\mathrm{R}_{\mathrm{s}} \mathrm{i}_{\alpha \mathrm{s}}+\mathrm{p} \psi_{\alpha \mathrm{s}} \\
& \mathrm{V}_{\mathrm{dr}}=\mathrm{R}_{\mathrm{r}} \mathrm{i}_{\mathrm{dr}}-\left(\omega_{\alpha}-\omega\right) \psi_{\mathrm{qr}}+\mathrm{p} \psi_{\mathrm{dr}} \\
& \mathrm{V}_{\mathrm{qr}}=\mathrm{R}_{\mathrm{r}} \mathrm{i}_{\mathrm{qr}}-\left(\omega_{\alpha}-\omega\right) \psi_{\mathrm{dr}}+\mathrm{p} \psi_{\mathrm{qr}} \\
& \mathrm{V}_{\mathrm{xr}}=\mathrm{R}_{\mathrm{r}} \mathrm{i}_{\mathrm{xr}}+\mathrm{p} \psi_{\mathrm{xr}} \\
& \mathrm{V}_{\mathrm{yr}}=\mathrm{R}_{\mathrm{r}} \mathrm{i}_{\mathrm{yr}}+\mathrm{p} \psi_{\mathrm{yr}} \\
& \mathrm{V}_{\alpha \mathrm{r}}=\mathrm{R}_{\mathrm{r}} \mathrm{i}_{\alpha \mathrm{r}}+\mathrm{p} \psi_{\alpha \mathrm{r}} \\
& \Psi_{\mathrm{ds}}=\left(\mathrm{L}_{\mathrm{is}}+\mathrm{L}_{\mathrm{im}}\right) \mathrm{i}_{\mathrm{ds}}+\mathrm{L}_{\mathrm{im}} \mathrm{i}_{\mathrm{dr}} \Psi_{\mathrm{dr}}=\left(\mathrm{L}_{\mathrm{ir}}+\mathrm{L}_{\mathrm{im}}\right) \mathrm{i}_{\mathrm{dr}}+\mathrm{L}_{\mathrm{im}} \mathrm{i}_{\mathrm{ds}} \\
& \Psi_{\mathrm{qs}}=\left(\mathrm{L}_{\mathrm{is}}+\mathrm{L}_{\mathrm{im}}\right) \mathrm{i}_{\mathrm{qs}}+\mathrm{L}_{\mathrm{im}} \mathrm{i}_{\mathrm{qr}} \Psi_{\mathrm{qr}}=\left(\mathrm{L}_{\mathrm{ir}}+\mathrm{L}_{\mathrm{im}}\right) \mathrm{i}_{\mathrm{qr}}+\mathrm{L}_{\mathrm{im}} \mathrm{i}_{\mathrm{qs}} \\
& \Psi_{\mathrm{xs}}=\mathrm{L}_{\mathrm{is}} \mathrm{i}_{\mathrm{xs}} \Psi_{\mathrm{xr}}=\mathrm{L}_{\mathrm{ir}} \mathrm{i}_{\mathrm{xr}} \\
& \Psi_{\mathrm{ys}}=\mathrm{L}_{\mathrm{is}} \mathrm{i}_{\mathrm{ys}} \quad \Psi_{\mathrm{yr}}=\mathrm{L}_{\mathrm{ir}} \mathrm{i}_{\mathrm{yr}} \\
& \Psi_{\alpha s}=\mathrm{L}_{\mathrm{is}} \mathrm{i}_{\alpha \mathrm{s}} \quad \Psi_{\alpha \mathrm{r}}=\mathrm{L}_{\mathrm{ir}} \mathrm{i}_{\alpha \mathrm{r}} \\
& \mathrm{T}_{\mathrm{e}}=\mathrm{PL} \mathrm{L}_{\mathrm{m}}\left[\mathrm{i}_{\mathrm{dr}} \mathrm{i}_{\mathrm{qs}}-\mathrm{i}_{\mathrm{ds}} \mathrm{i}_{\mathrm{qr}}\right]
\end{aligned}
$$

\section{CONTROL SCHEME}

The closed loop performance of IM drive is depends on switching pattern of VSC converter. The main advantage of PWM technique it does not need any additional control strategy to generate the pulses. In this SPWM technique sinusoidal wave is consider as carrier wave and triangular is reference wave, whenever a magnitude of carrier wave is higher than triangular wave pulse will be generates accordingly. The MATLAB design of switching pattern of VSC with SPWM technique is configured in fig. $2 \mathrm{a}$. 


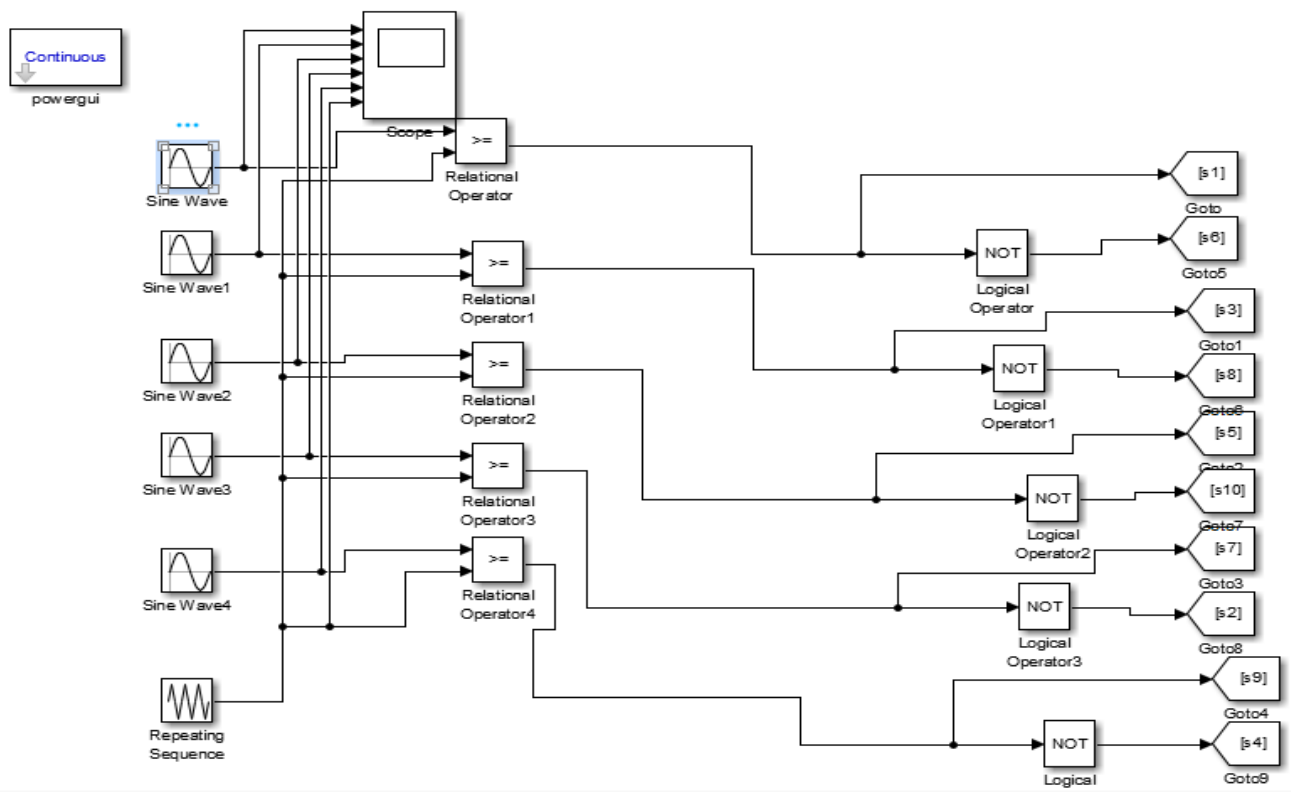

Figure 2a: Switch Pattern of VSC with Sinusoidal PWM Technique.

The schematic diagram of VSC fed five phases IM drive is shown in fig.2b.

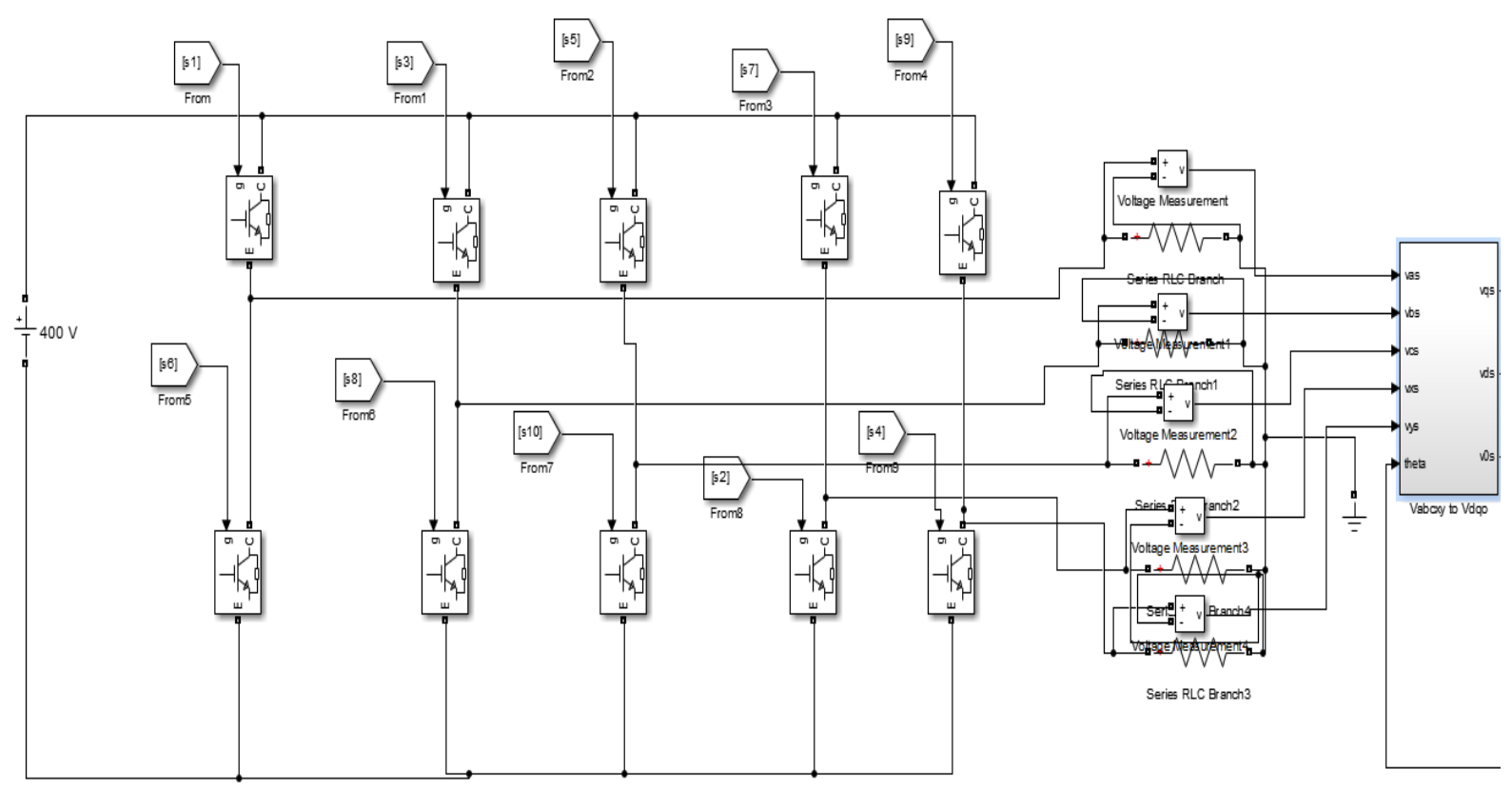

Figure 2b: MATLAB Model of VSC.

The output of 5 phase inverter voltage is shown in fig.2c. 

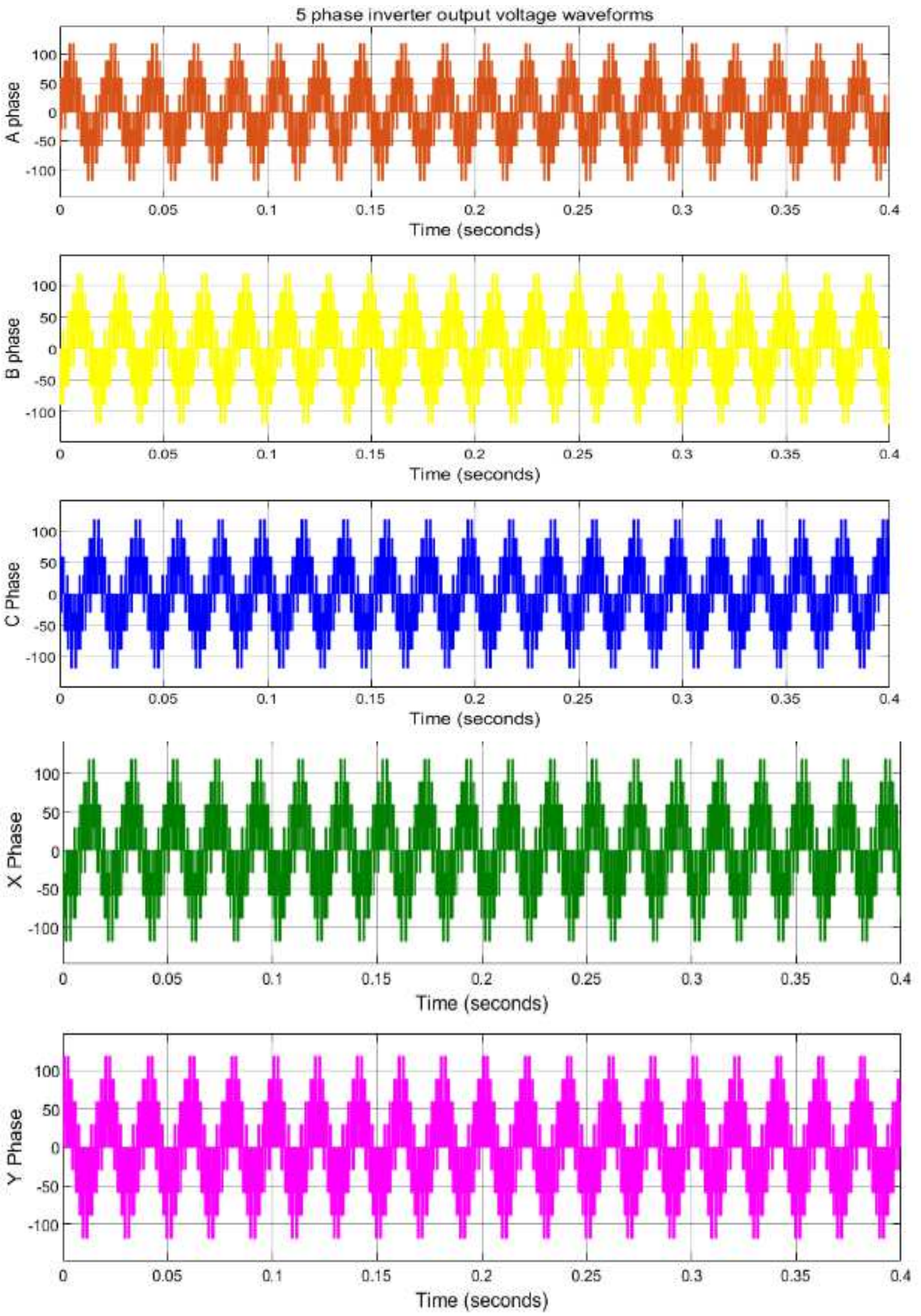

Figure 2c: MATLAB Output of VSC. 


\section{SIMULATION RESULTS}

The schematic MATLAB model of five phases IM is exposed in fig. 3 below.

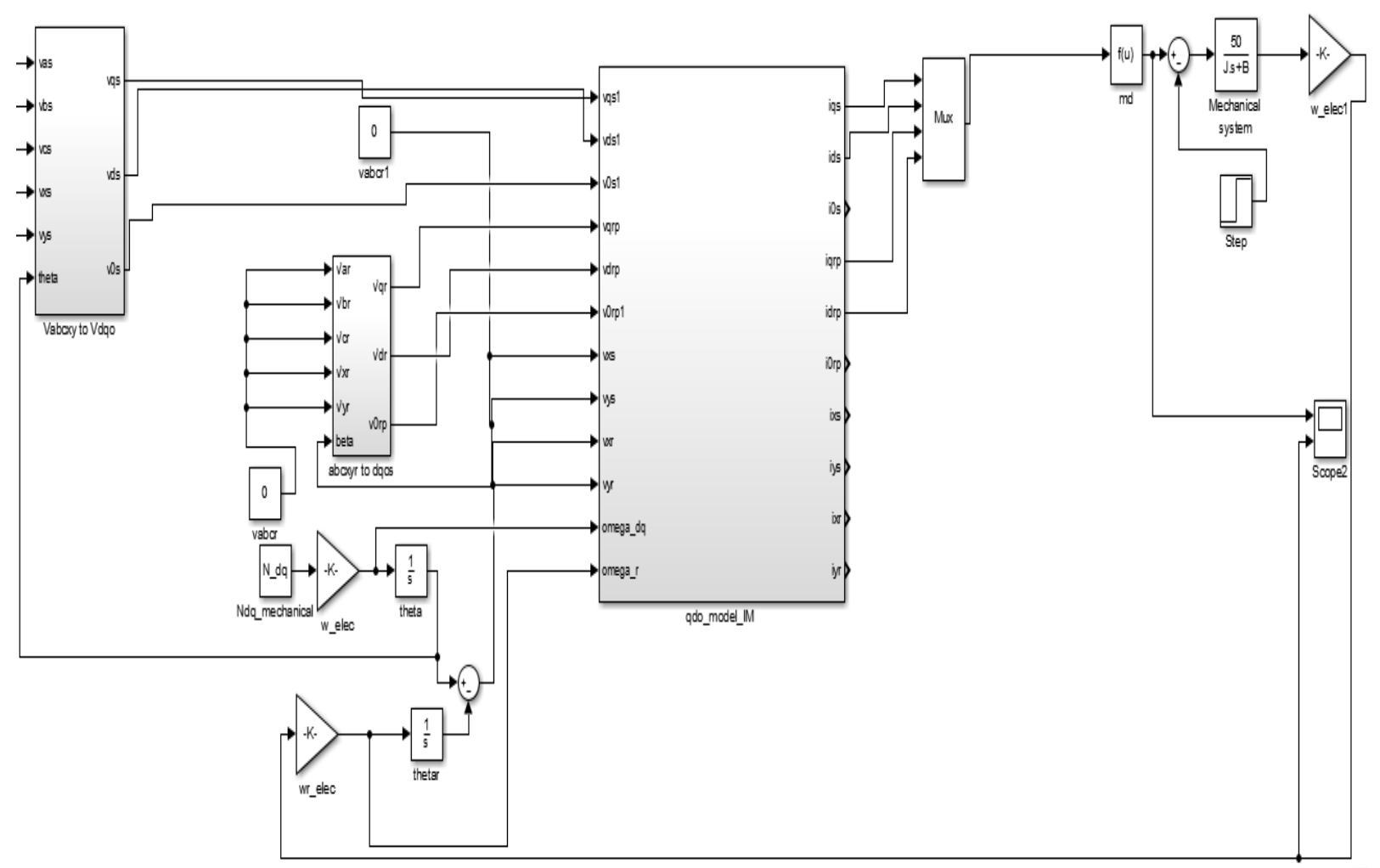

Figure 3: MATLAB Model of Five Phase IM.

The voltage supplied to the stator of the IM is $150 \mathrm{~V}$ illustrates in fig.4

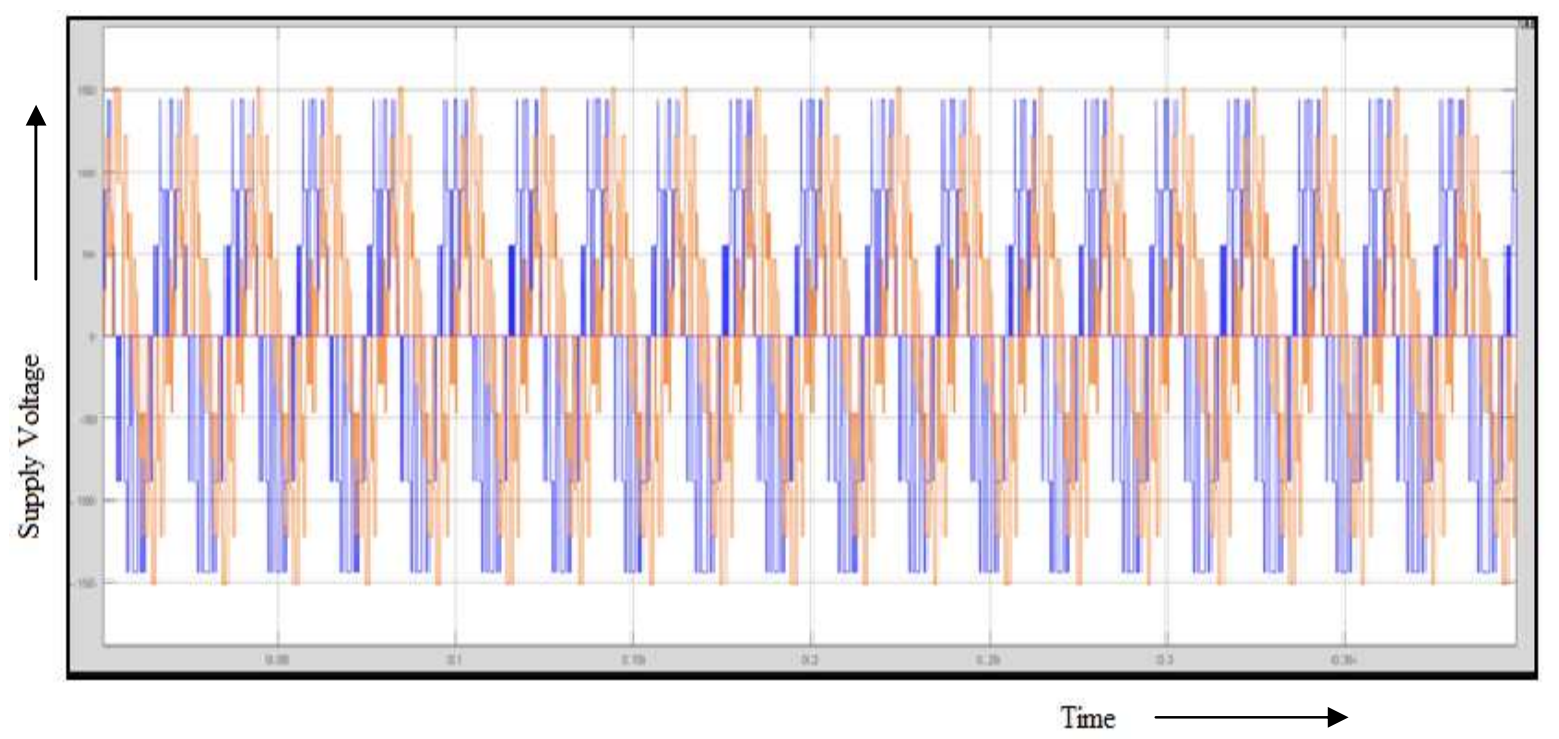

Figure 4: Stator Voltage. 
The variation of stator side parameters are described in fig.5.

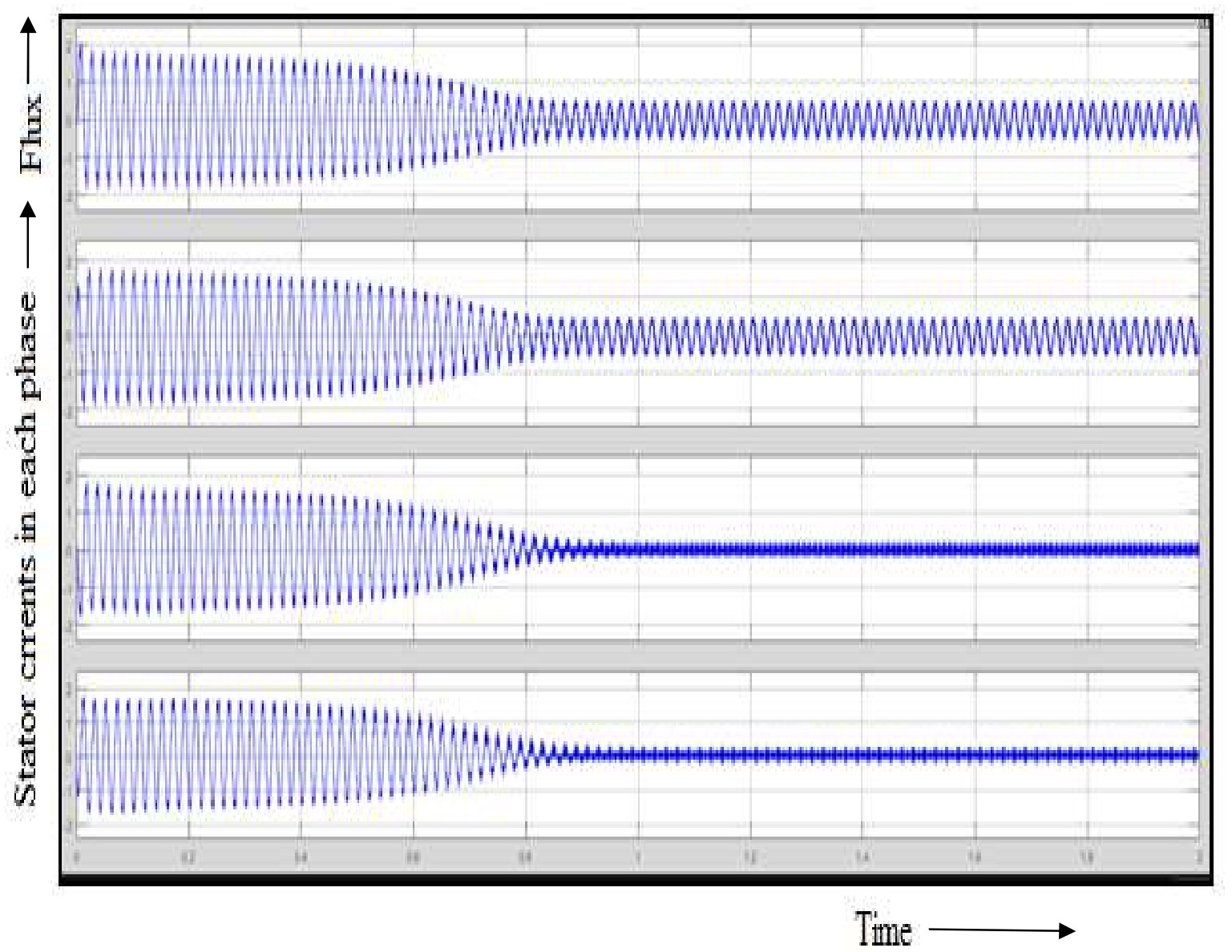

Figure 5: Variation of Stator Parameters.

The obtained torque response of the IM with SPWM technique is shown in fig.6 below

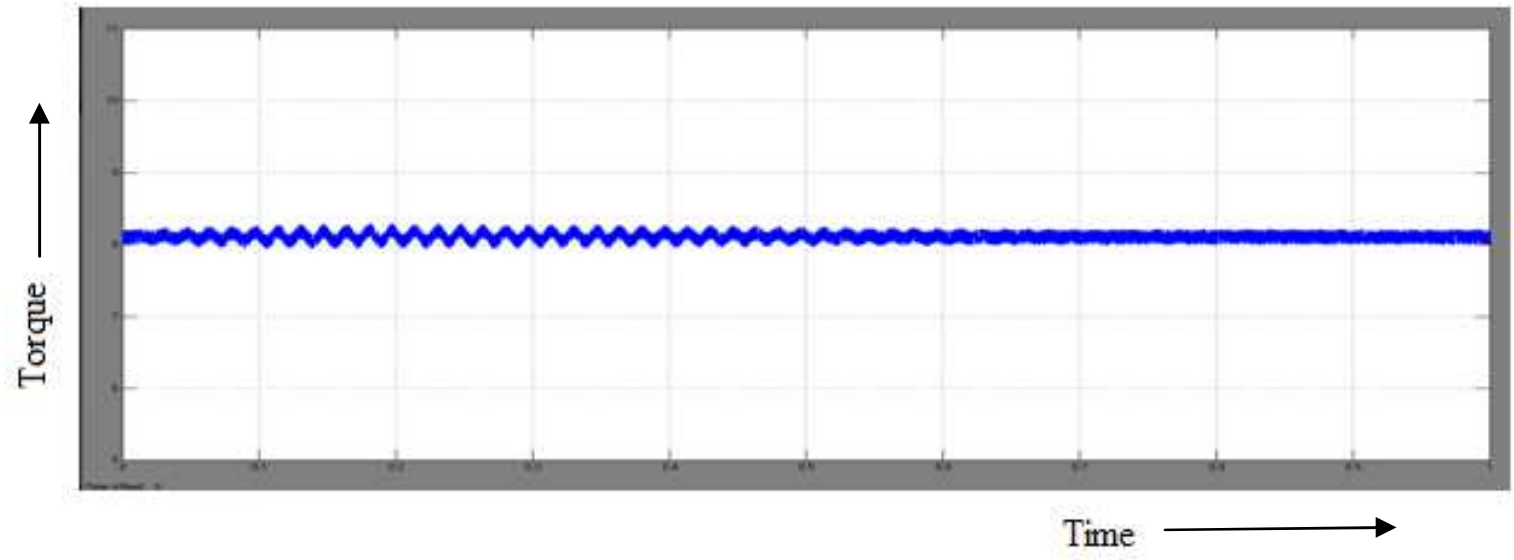

Figure 6: Torque Response of Five Phase IM.

From the torque response the IM is clear that the ripple or oscillation occurrence is very less compare to the conventional control strategies fed five phase IM

The obtained speed response of the five phase IM is exposed in fig.7. 


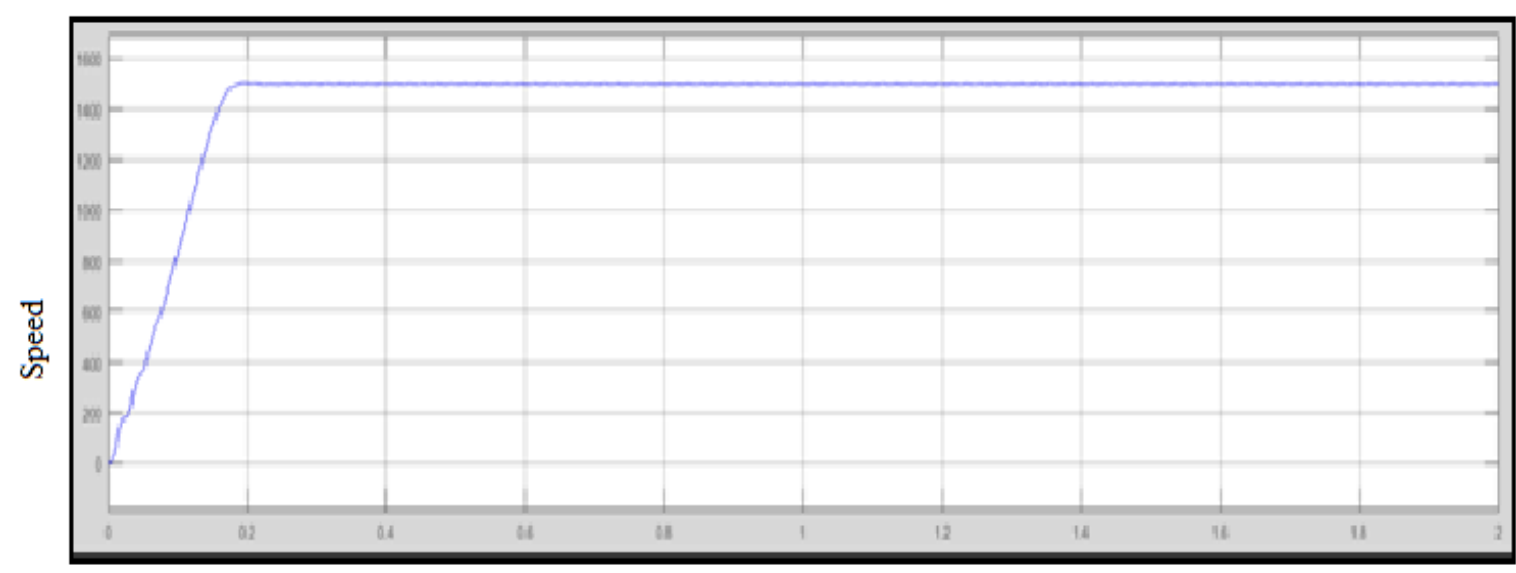

Time

Figure 7: Speed Response of the IM.

Fig.7 evident that almost constant speed and i.e. near to the synchronous speed (1480 rpm) is achieved with proposed PWM control technique.

\section{CONCLUSIONS}

The mathematical model of 5 phase IM and its performance characteristics with SPWM is investigated in this article. Less power electronic components are utilised to drive IM so this proposed control technique is more economical over conventional control techniques fed IM drive. Fixed ripple free torque response and speed can be obtained with employing SPWM technique. Improved steady state/dynamic performance of IM drive is achieved with adopting proposed control scheme.

\section{ACKNOWLEDGEMENTS}

Authors are grateful to SR Engineering College, Warangal for providing financial assistance to carried out this research work.

\section{REFERENCES}

1. V. D. Kore, K. M. Pisolkar, V. Joshi, A. Bhurke and K. M. Isane, "5-level cascade H bridge multilevel inverter fed induction motor drive using sinusoidal PWM," 2019 2nd International Conference on Intelligent Computing, Instrumentation and Control Technologies (ICICICT), Kannur,Kerala, India, 2019, pp. 1074-1078,

2. P. Palanivel and S.S. Dash, "Analysis of THO and output voltage performance for cascaded multilevel inverter using carrier pulse width modulation techniques, "IET Power Electron. Vol. 4, Iss. 8, pp. 95I-958, Mar.2011

3. McGrath, B.P.; Holmes, D.G.; "Multicarrier PWM strategies for multilevel inverters , ", IEEE Trans. Ind. Electron, vo1.49, no.4, pp. 858- 867, Aug 2002

4. I. Takahashi and T. Noguchi, "A new quick-response and high efficiency control strategy of an induction motor," IEEE Trans. Ind.Appl., vol. IA-22, no.5, pp. 820-827, September 1986.

5. Eashwaramma, N., J. Praveen, and M. Vijayakumar. "Reduced Number of Power Switches in Multi Level Inverter Using Spwm Technique to Mitigate for Sag and Swell."International Journal of Applied Engineering Research and Development (IJAERD) 8. 1, Jun 2018, 1-10 
6. D. Casadei, F. Profumo, G. Serra, and A. Tani, "FOC and DTC: two viable schemes for induction motors torque control," IEEE Trans. Power Electron., vol.17, no.5, pp. 779-787, September 2002.

7. AbhilashaParthan, L. Padma, and J. R. Anoop Raj, "A brief review on torque control of induction motor," IEEE ICCPCT 2017, pp. 1-5, April 2017.

8. T. Vinay Kumar and S. Srinivasa, "Direct torque control method for induction motor drives based on modified amplitude and angle decoupled control of stator flux, " IEEE PEDES 2010, pp. 1-6, December 2010.

9. N. Pimkumwong, A. Onkrong, and T. Sapaklom, "Modeling and simulation of direct torque control induction motor drives via constant Volt/Hertz technique," Elsevier Procedia Engineering, vol.31, pp. 1211- 1216, February 2012

10. Kavali, Janardhan, and Arvind Mittal."Analysis of various control schemes for minimal Total Harmonic Distortion in cascaded H-bridge multilevel inverter." Journal of Electrical Systems and Information Technology 3.3 (2016): 428-441.

11. K. Saidi, M. Maamoun, and M. Bounekhla, "Simulation and analysis of variable step size P\&O MPPT algorithm for photovoltaic power control," in Proc. IEEE GECS, pp. 1-4, March 2017.

12. D. Casadei, F. Profumo, G. Serra, and A. Tani, "FOC and DTC: Two viable schemes for induction motors torque control," IEEE Trans. Power Electron., vol. 17, no. 5, pp. 779-787, Sep. 2002.

13. E. Levi, Multiphase Electric Machine for Variable Speed Applications, IEEE Trans. On Industrial Electronics, vol. 55, no. 5, pp. 1893-1909, 2008

14. E. Levi, R. Bojoi, F. Profumo, H.A. Toliyat, S. Williamson, Multiphase induction motor drives-A technology status review, IET Electric Power Applications, vol. 1, no. 4, pp. 489-516, 2007.

15. Brahmaiah, C., C H Srinivas Rao, and M. Baba Fakruddin."A Series-Connected Multilevel Inverter Topology for MediumVoltage BLDC Motor Drive Applications." International Journal of Electrical, Electronics and Data Communication 1.10 (2013): 55-60.

16. L. Gao, J.E. Fletcher, L. Zheng, Low-speed control improvements for a two-level five-phase inverter-fed induction machine using classic direct torque control, IEEE Trans. On Industrial Electronics,vol. 58, no. 7, pp.2744- 2754, 2011.

17. H. Miranda, P. Cortés, J.I. Yuz, J. Rodríguez, Predictive Torque Control of Induction Machines Based on State-Space Models, IEEE Trans. on Industrial Electronics, vol. 56, no. 6, pp. 1916-1924, 2009.

18. Deshpande, Soham G., and N R Bhasme. "Modeling and Simulation of Microinverter with Flyback Converter for Grid Connected PV Systems. "International Journal of Electrical and Electronics Engineering Research (IJEEER) 7. 4, Aug 2017, $71-82$

19. M. E. Romero, M. M. Seron, and G. C. Goodwin, "A combined model predictive contol/space vector modulation (MPC-SVM) strategy for direct torque and flux control of induction motors,” in Proc. IECON Conf., 2011, pp. 1674-1679. 

